\title{
Stories of water: preschool children's engagement with water purification
}

\author{
Teresa Elkin Postila ${ }^{1}$ (D)
}

Received: 12 May 2020 / Accepted: 4 July 2021 / Published online: 16 September 2021

(c) The Author(s) 2021

\begin{abstract}
This article aims to investigate environmental education in preschools by taking Donna Haraway's call of staying with the trouble together with preschool children seriously, hereand-now, in explorations of dirty water and water purification. This posthumanist inspired research project draws theoretically and methodologically on the writings of Haraway, Anna L. Tsing and Isabelle Stengers. The empirical data consist of three stories from a multidisciplinary intervention research project in the Stockholm region in Sweden, collected from collaboratively produced data such as films, photographs, drawings, and notes from the project. The study can be seen as an invitation to preschools to engage in the debate on climate change and to create a togetherness around environmental concerns, not only in the future, but also here-and-now in the preschool.
\end{abstract}

Keywords Early childhood education - Geoscience $\cdot$ Environment education · Water purification $\cdot$ Posthumanist intervention research

\begin{abstract}
Abstrakt
Den här artikeln undersöker miljöundervisning i förskolan genom att ta Donna Haraways uppmaning att stanna kvar i problemen (staying with the trouble) på allvar ihop med förskolebarn, här-och-nu, i utforskande av smutsigt vatten och vattenrening. Det posthumanistiskt inspirerade forskningsprojektet och dess analys utgår teoretiskt och metodologiskt från texter av Haraway, Anna L. Tsing och Isabelle Stengers. Artikeln uppmärksammar tre berättelser där förskolebarn och en forskare undersöker vattenrening i ett multidisciplinärt interventionsforskningsprojekt genomfört i Stockholmsregionen, Sverige. Dessa berättelser är ihopsatta av samproducerade data bestående av filmer, fotografier, teckningar och anteckningar från projektet. Studien kan ses som en inbjudan till förskolan att engagera sig i debatten om klimatförändringarna, och skapa gemenskap kring miljöfrågor, inte bara för framtiden utan också här och nu i förskolan.
\end{abstract}

Nyckelord Förskolan · Geovetenskap · Miljöutbildning · Vattenrening · Posthumanistisk interventionsforskning

Lead Editor: Maria Andrée

Teresa Elkin Postila

teresa.elkin.postila@buv.su.se

1 Department of Child and Youth Studies, Stockholm University, 10691 Stockholm, Sweden 
Contemporary research across scientific disciplines addresses climate change and environmental issues, such as water shortages and polluted seas and streams, where access to clean water is uncertain both now and, in the future, as seen for example in the IPCC technical paper on climate change and water (Bates, Kundzewicz, Wu, \& Palutikof, 2008). These scientific reports challenge how climate change and water are addressed and approached with young children. Inviting children to take part in today's ecological debate and finding other ways of engaging young children, as well as engaging as adults with children in environmental issues concerning water have been given urgency, for example in preschools, where questions about clean water and how to save water are important topics to investigate.

This article draws on previous posthuman and new materialist early childhood education (ECE) research focussing children's relations with matter in the particular and the local, as for example the co-emergence of informal environmental learning in being-with child/water/dirt/clay relations in an Australian context (Crinall \& Somerville, 2020) and engaging with local environmental vulnerability together with children, water, and indigenous knowledge in a North American context (Nxumalo \& Villanueva, 2019). This article draws attention to approaching the global problem of environmental issues by engaging with what emerges in young children and everyday local water activities, part of preschool practices.

Children attending Swedish preschools are used to exploring and playing in and with water, snow and ice, and learning with and about their ecological surroundings as part of their everyday pedagogical activities. This is in line with the Swedish preschool curriculum, which states that education in the preschool should provide an opportunity for children to adopt a caring approach to their surrounding environment, characterised by a positive belief in the future (Swedish National Agency for Education, 2018). Accordingly, preschools have a two-pronged mission of inviting children to explore, reflect on and work with issues relating to climate change and water, as well as creating pedagogical activities and spaces in which children can establish and maintain optimism about the future. Both these aspects of pedagogical work involve different ethical challenges and fundamental questions related to being in and of the world. In this article, this two-pronged mission is acknowledged and investigated in explorative practices of thinking, hesitating and imagining together with young children.

The aim of this article is to rethink environmental education in preschool by taking Donna Haraway's (2016) call of staying with the trouble seriously by engaging with preschool children in investigations of dirty water and water purification. Haraway (2016, p. 1) writes that staying with the trouble is about learning to be truly present, "entwined in myriad unfinished configurations of place, times, matters, meaning", which is challenging both for children and adults. This here-and-now practice was produced, during a 9-month long field period with a researcher and preschool children in Sweden's Stockholm region. In this explorative and multidisciplinary intervention project, I Teresa, an ECE researcher with a background in the geosciences and ECE, situated myself in two preschools' ongoing, explorative, pedagogical practices (The posthumanist intervention research project is framed by the united nations convention on the rights of the child (UNCRC) (UN, 1989), Act concerning the ethical review of research involving human beings (SFS, 2003:460), Good Research Practice (Swedish Research Council, 2017) and the General Data Protection Regulation (EU, 2016/679) (European Parliament and Council, 2016). These frameworks draw on the Universal Declaration of Human Rights (UDHR) (UN, 1948) and the World Medical Association (WMA) Declaration of Helsinki (WMA 1964, revised 2008). The project as been treated by the Swedish Ethical Review Authority. The research project was conducted at two preschools located in two 
different socio-economic heterogenic areas in the same municipality. Many of the children had travelled abroad and some had experience of living in another country than Sweden.). My project draws on earlier research where the researcher have situated themselves in preschool practices to investigate different research questions, from "within" the practices, together with those engaging in the practice, 1-2-year-old preschool children (Eriksson, 2020) and preschool staff (Aronsson, 2019). Accordingly, I intervened in the preschool children's everyday pedagogical practices as a curious, interested, and collaborative partner with expertise in the geosciences and their methods. The pedagogical practices involved activities such as constructing with recycled materials, pedagogical documentation, and reflection practices, often used in Swedish preschools (Åberg \& Lenz Taguchi, 2018). During our collaborative explorations of water, facts, and methods from the geosciences emerged as important to generate and maintain the children's and my own interest in water purification. The entangling of different practices and methods emerged as multidisciplinary bridge-building practices of togetherness. In these multidisciplinary practices, meetings between disciplines, knowledge, terminology, methods, and expertise, produced alternative solutions and ideas (Stengers, 2010).

The subsequent analysis draws theoretically and methodology on the writings of Haraway (2016), Isabelle Stengers (2010, 2018) and Anna L. Tsing (2015). With inspiration from these scholars, I have stayed with and unfolded water's intricate relations with young children, existential issues, and vulnerability. Moreover, water's local multiple relations connect with different scientific disciplines and geographical distances. In this context, Stengers' (2018) call for science to be performed in close collaboration with those it concerns, starting in the local and what matters to those living there, has been inspiring. Although Stengers (2010, 2018) does not explicitly write about children, I have been encouraged by how she addresses and invites the public and "connoisseurs" to intervene in research. According to Stengers (2018), a connoisseur is an expert with specific "situated knowledges" in a particular milieu, which in research contributes as a producer of local knowledge, rather than delivering data or facts to the researchers. In this article the children are the connoisseurs and are involved in locally situated time-place research to investigate and rethink environmental education through their concerns to cleaning dirty water.

As already addressed, the research project connects to previous ECE research involving young children, other actors and environmental issues, focussing on what is produced in the local and everyday practices' relations. In addition to the already mentioned studies this article also relates to the posthuman approach of multispecies ethnographies, for instance projects concerning what learning is produced in earthworms', ants', and children's meetings (Taylor and Pacini-Ketchabaw, 2015) and existential questions in relation to preschool pets (Nxumalo \& Pacini-Ketchebaw, 2017). These research studies have motivated me to focus on children's everyday relations and how the children are involved in the more-than-human world by drawing attention to "minor stories featuring minor players" (Taylor, 2020, p. 353). I am also inspired by previous ECE research studies drawing on a posthuman theoretical framework, concerning young children's engagement with water and dirt in the everyday (Crinall \& Somerville, 2020) and children's engagement with water and indigenous knowledge (Nxumalo \& Villanueva, 2019). 


\section{Narrative writing and weaving stories together as practice}

In this article I employ a narrative style of writing, which is most evident in the analysis section. I have engaged with the stories produced by the children in the project and connected them with stories from science, technology, and fiction. Tsing (2015, p. 38) writes, "To listen to and tell a rush of stories is a method", which might contribute to other perspectives and points of view and propose a crucial analysis. The preschool children, as the local connoisseurs, and I, told and listened to stories as a practice of caring and thinking (Stengers, 2018) throughout the field period. Furthermore, I engaged with stories about water, and how to clean it, that were produced by preschool children in their own settings and materialised in texts, photographs, drawings, and films. These stories are created together with theory and are interwoven with earlier research on explorative pedagogy, science and the geosciences. I have also connected to memories and other stories that emerged as being important, during the children's exploratory work. By weaving facts with fiction, art with science and connecting the stories to theory, narratives are produced, as Haraway (2016) explains. To employ a narrative analysis is about listening, both to the children's stories and to what the stories relate to and are concerned with.

The stories I have constructed for this article consist of many minor stories and cannot always be neatly scaled or put in an intelligible order (Tsing, 2015). As Stengers (2010) writes, it is the researchers' responsibility to organise the analysis in a way that is readable, makes sense, and at the same time acknowledges that the narratives are produced in relation to something or someone. Stengers (2010) also writes that when researchers slow down and pay attention to values, obligations and responsibilities, the stories emerge as important, in this case the preschool children's stories about water and how to clean it. The importance of the matter of concern resonates in the project not only quantitatively but also qualitatively (Stengers, 2018), and shows that the children's engagement with water and how to clean water has been extensively investigated, experimented with and documented in different ways.

Three stories are included in the analysis: the story of solar energy, the story of water filtration machines and water robots and the story of testing, all of which were produced collaboratively by the preschool children, their teachers, me, the water and the various constructions that were built. These stories were collected from the 46 children's personal diaries, two project diaries, film sequences, photographs and my fieldnotes that were produced during the field period. The chosen stories were partly analysed and modified already during the field period, while I and the children wrote them, read them aloud, listened to them together and assembled them into picture-presentations (The picture-presentations were ensembled in the window-based software program PowerPoint.). The stories presented here have accordingly been documented in various ways, in drawings, photographs, films and memos. Therefore, as Tsing (2015, p. viii) writes, the photographs, (Figs. 1, 2, 3, 4, 5 , $6,7)$, included in this article "tell a story alongside the text but do not illustrate it directly".

\section{The project's setting and design}

The project's setting and design involves the children's own localities and neighbourhoods, namely familiar landscapes and preschool settings. This way of doing research draws on Haraway's (1988) notion of "situated knowledge", which in this project is 


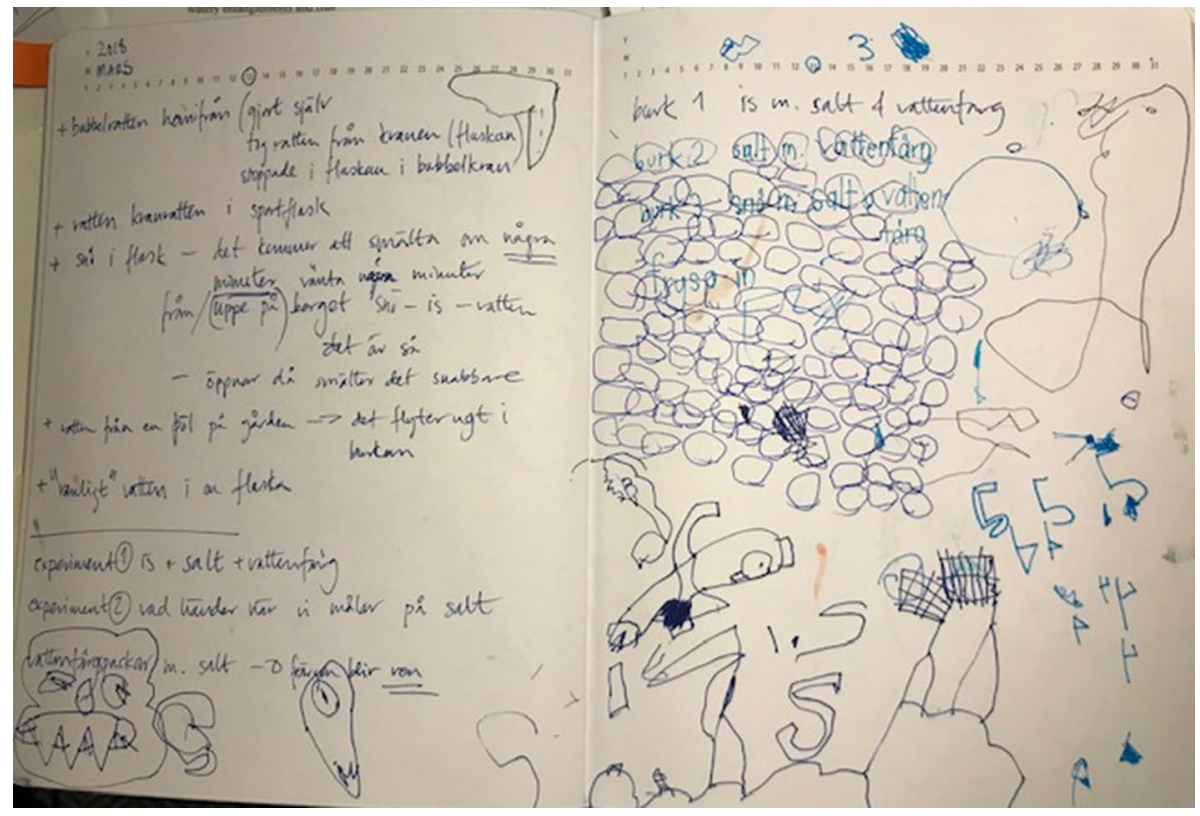

Fig. 1 Notes and drawings of questions to investigate

Fig. 2 Maja's first hypothesis on cleaning water by solar energy

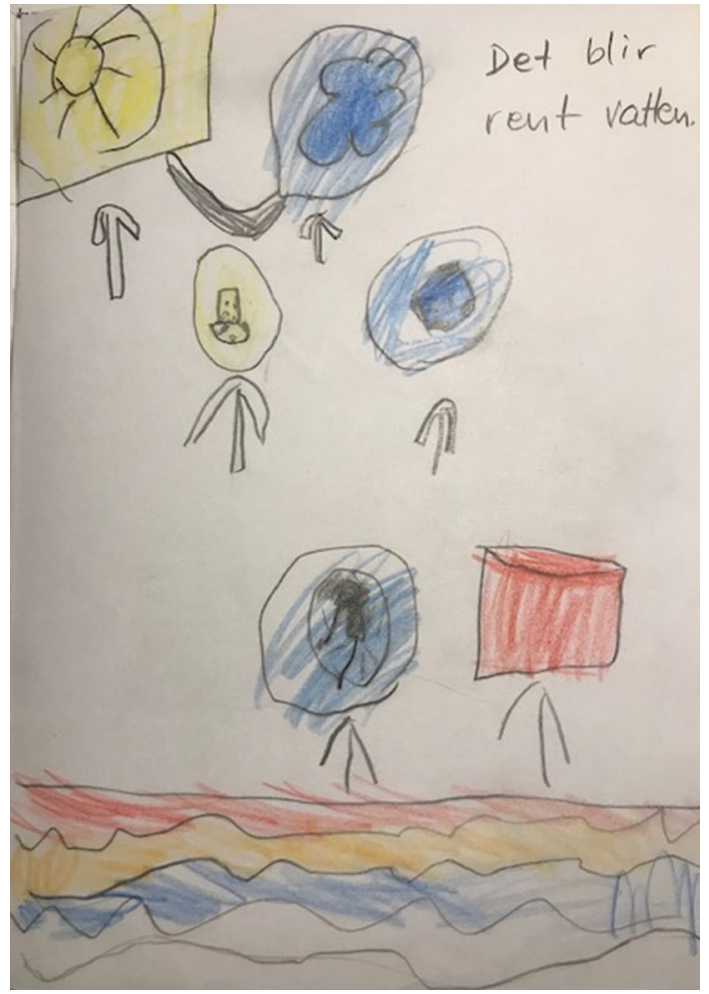




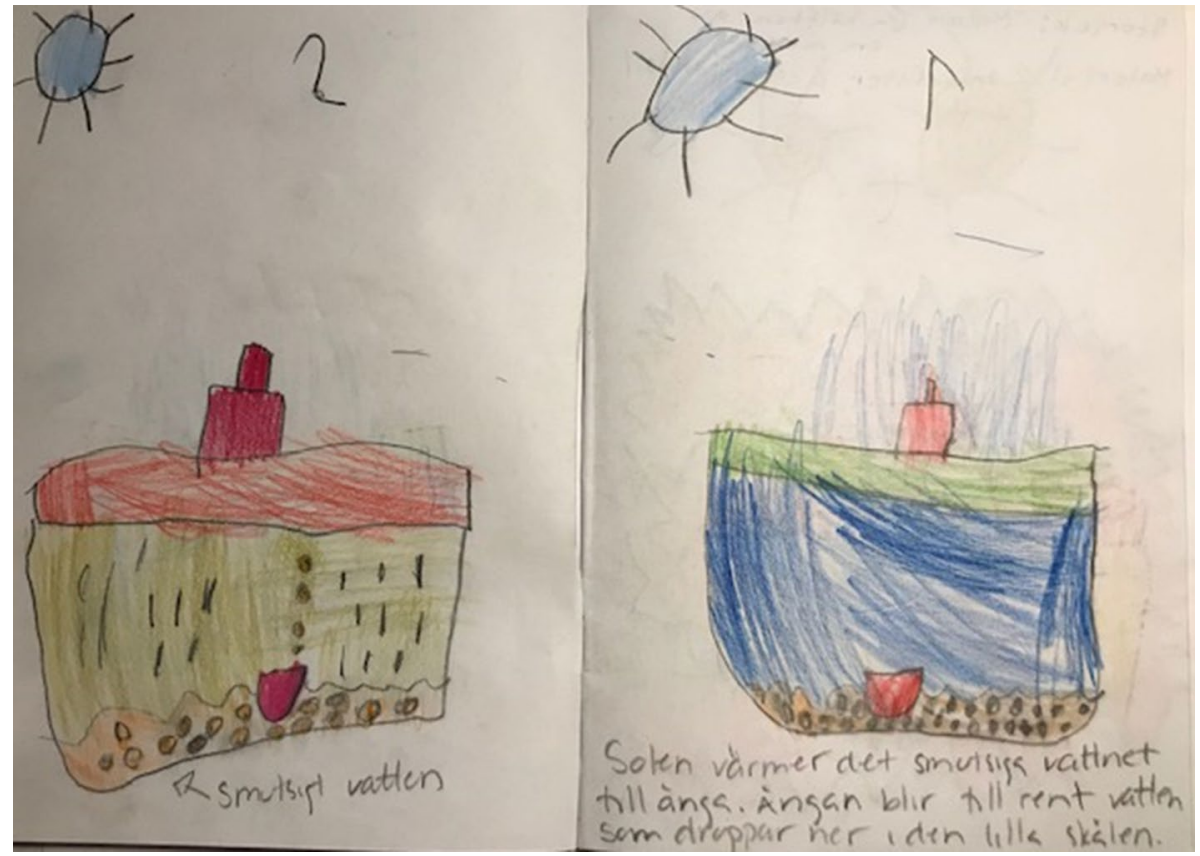

Fig. 3 Maja's second hypothesis on cleaning water by solar energy

about situatedness as in creating "here-and-now-spaces" with children, where they can investigate their concerns, motivated by curiosity and supported by adults. Therefore, it is important to emphasise that the research project's field period took place in a coastal region with an abundance of freshwater lakes, bare bedrock outcrops, small valleys and coniferous and mixed forests. For the preschool children involved in the project, these were their local, well-known surroundings and easily accessible by foot. However, the preschools' immediate surroundings were dominated by terraced houses, blocks of flats, asphalted walkways, cycle tracks, busy roads, railway lines, lawns and gardens. Prior to the field period the participating children were divided into different explorative groups by their preschool teachers, with one or two teachers assigned to each group. These groups met with me once or twice every second week to investigate water and examine ways of purifying it both inside the preschool and outdoors. The preschool teachers' pedagogical experience and their knowledge about each individual child conditioned the research process, in that they supported individual children and assisted both the children and me in our collaborative explorations of water. Moreover, the teachers were closely involved in scheduling the explorative meetings together with me. The methodological approach of involving the preschool teachers, deciding on which child should be part of which group and staying close to the preschools' ordinary schedules served two purposes: it guaranteed the preschool teachers' supportive participation and ensured access to the preschools' different rooms and materials. The groups were often scheduled to meet in the mornings and the children knew which group they belonged to and which teacher belonged to their group. 
Fig. 4 Maja's water filtration machine
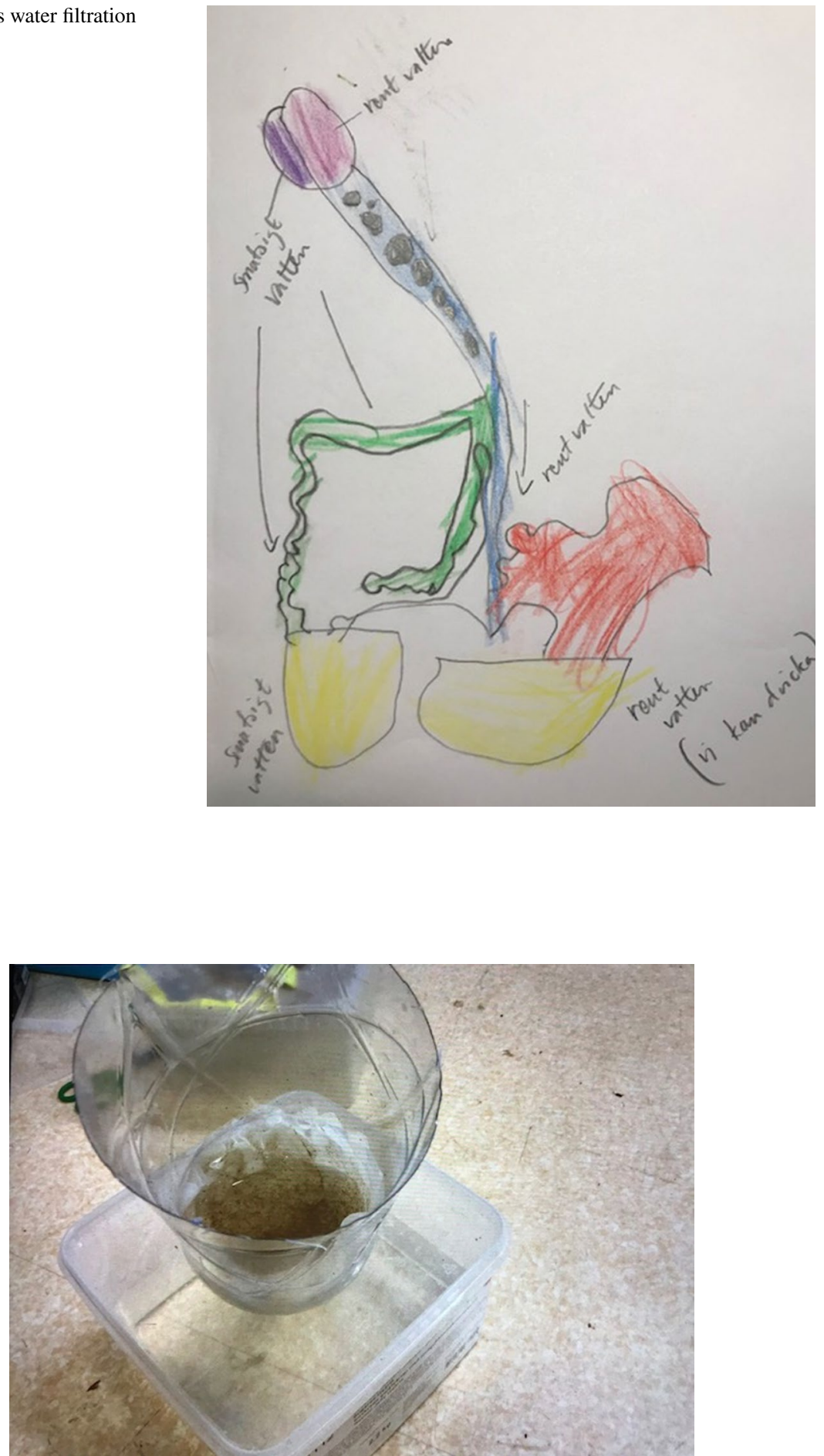

Fig. 5 Elias's water filtration machine 
Fig. 6 Elsa's water filtration machine

Fig. 7 Water filtration machine with three filters and two containers
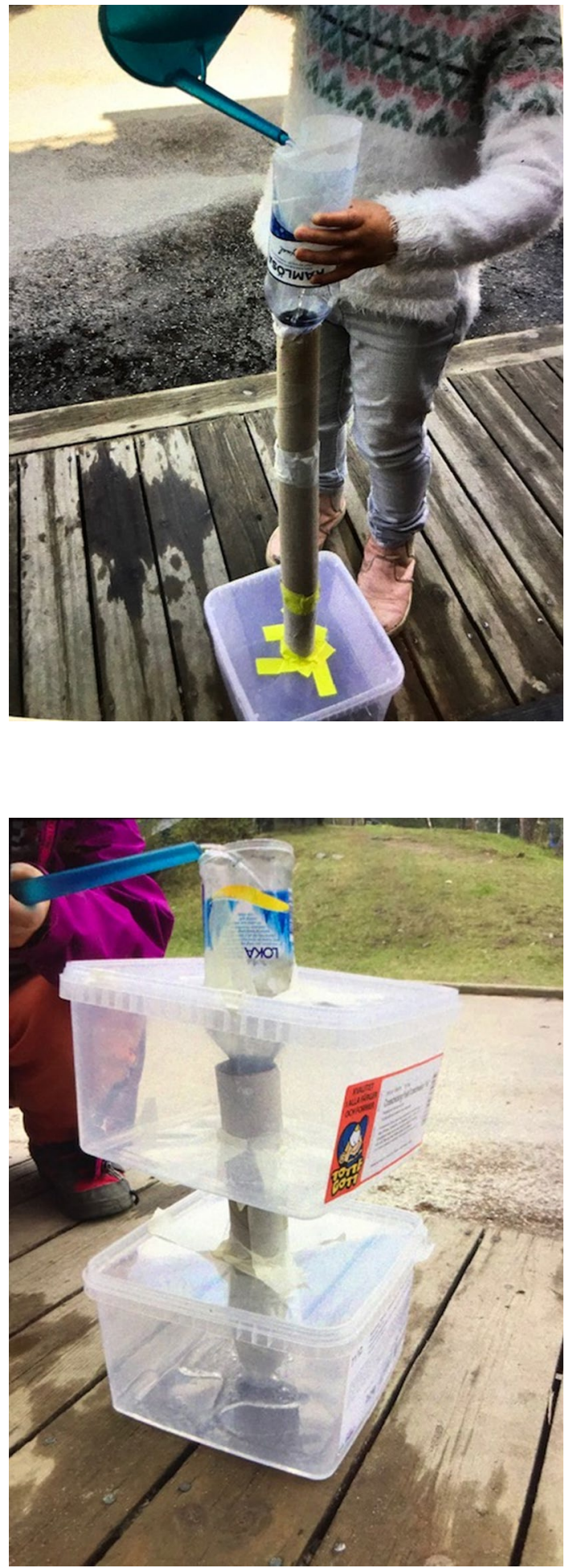


\section{Situating myself as a researcher in ongoing preschool practices}

Early on the first day of the project when I approached the preschool, I heard the familiar preschool sounds of outdoor play on a snowy day in a preschool yard. Though the snow muffled the intricate mixture of children's and adults' voices, fast moving bodies, sliding sounds, the cracking of ice and digging and various other sounds could be distinguished. The children and their teachers were carrying on with their activities of checking in the children on their digital tablets, saying good-bye to guardians, opening the doors on the small storage shed to fetch buckets, spades and baking tins, conversing with each other, running up the hill and sliding down. In this project, I situated myself in the already existing and ongoing preschool practices, the activities and routines mentioned above, and accordingly I interacted with and in the preschool children's and their teachers' practices. As indicated above I had experience of preschool practices and was also familiar with explorative teaching methods. However, from an ethical research perspective, it was important for everyone involved in the research project to be informed about my role, both in the project and at the preschool (Swedish Research Council, 2017). This meant that I first presented my research project and its aims to the preschool teachers and the children's guardians at scheduled evening meetings at the two preschools. The information to the preschool teachers involved highlighting their participation and role in the project, which was mainly to support and assist the children and support me during the explorations of water (Information was also provided regarding safety measurements during the field period such as the use of life vests in the close premises of open water and safety vests while on excursions.). The guardians were informed that the children's participation in the research project was voluntary, that the children and I would document the exploratory process and that the documentation would be anonymised before publication (Information was also provided regarding safety measurements during the field period such as the use of life vests in the close premises of open water and safety vests while on excursions.). During these information, meeting details about the research project were also distributed in writing. Consent forms were also distributed to be read, signed and returned to me.

All preschool children were given similar information verbally, although in a more child-appropriate way (SFS, 2003: 460), which involved an exploration of my interest in engaging and exploring water together with the children both outdoors and indoors. I also informed the children that before each meeting I would ask each child: Would you like to explore water with me today? and that they could then answer yes or no. Here, I emphasised that even if the child had agreed to participate, they always had the option of changing their minds during the activities and could leave whenever they wanted to (Swedish Research Council, 2017). Accordingly, during the project some children lost interest in the exploration in a specific moment and stated that they did not want to participate or listen to me. For example, Elsa, who during lunch told me: Do you know Teresa why I did not want to explore water today? I thought you explained things so badly (All names used in the article are pseudonyms (European Parliament and Council, 2016) collected randomly from the 100 most common names of newborn children in Sweden in the year 2019 (Statistics Sweden, 2020a, b). Tanzania is also a pseudonym for another African country (European Parliament and Council, 2016).). The children showed verbally and physically whether or not they wanted to participate in the explorative meetings with me.

During the project we got to know each other, and I became acquainted with the children's everyday environments and practices and the teachers' routines and work schedules. In order to encourage engagement, I explored how to include the children's ideas and 
questions and negotiate different understandings and ways of doing things. I explained to the children that I would support them during their explorations of water and that they could document their explorations, questions, reasoning and findings in films, photographs, drawings, and notes, and talk about their findings with each other, their teachers and of course with me. I also told the children that they would be able to decide which photographs and films I could take back to the university to analyse after the field period. I encouraged the children to make their own choices about which digital documentation they wanted to keep or delete. In this context, I showed them the wastepaper-basket-symbol on the digital tablet's screen and how to delete films and photographs.

Before I joined the different groups of children and began the exploratory work, I also spent some time with the teachers. During this phase the teachers and I discussed their different responsibilities during the study and during the excursions and all the other activities. We also discussed at what time during the day it would be most appropriate, in relation to other activities at the preschool, for the explorative meetings to take place. The teachers helped me to plan the project and make decisions about how, and in what ways, it could occur in the daily schedule of the preschools. During the continuous ongoing process of getting-to-know each other, the presence of the teachers was important for both the children and me. The teachers' presence, 1-2 teachers in each explorative group during the meetings with the children, affected the interactions within the groups. The teachers supported the children in expressing themselves and helped out by connecting and relating conversations and activities during the field period to things done previous at the preschool. The teachers and the children proposed different possible directions the project could take and negotiated with me around different options; for example, when proposing possible sites to investigate water in situ and planning together for excursions. Without the input from and the participation of the teachers, excursions to different water bodies would have been difficult to organise and realise, for example due to safety aspects (Before and during excursions to the Baltic Sea and different fresh water bodies we followed Swedish Civil Contingencies Agency's (2020) safety instructions for children by the water.). The teachers also had direct contact to the children's guardians and could therefore inform about practicalities and prepare the guardians in advance before excursions. Accordingly, the teachers helped with all practicalities and supported me in my endeavours to be fully present together with the preschool children.

In order to encourage engagement, I explored how to include the children's ideas and questions and negotiate different understandings and ways of doing things. In this explorative work, which at times was very chaotic, I made use of my previous experiences from preschools to slow down the pace, rather than rushing to the next activity in the explorative meetings. The process of slowing down in the children's here-and-now spaces provided time to think, feel, and imagine without being rushed and allowed me to affirm and welcome the children's different suggestions, in which different thoughts emerged. However, to stay with the trouble, at times meant stubbornly holding on to questions about water rather than following other ideas and interests.

\section{A multidisciplinary bridge-building practice of togetherness}

In this part of the article I summarise the methods from explorative pedagogy and the geosciences that emerged as important during the explorative meetings with the children. I regarded the research design as a multidisciplinary bridge-building practice in which 
theory and methods were combined and sometimes woven together to produce engagement and collaboration together with the preschool children and water. This meant weaving the preschool children's questions with scientific facts and methods in a practice of togetherness and acknowledging this as involving multidisciplinary approaches rather than consensus (Aronsson, 2019), thereby aligning with Stengers' (2018) suggestion of a slower science performed carefully and together with those concerned and with questions that matter to those who are involved. The children's interests, questions and curiosity produced opportunities for multidisciplinary bridge-building curious practices. These practices produced open, interesting possibilities, in which we were surprised, interested and frustrated. The construction of a we in research is about thinking together, not only with other people but with the world and all its organisms. Stengers (2018, p. 145) writes: "What matters is rather the possibility of creating relevant modes of togetherness between practices, both scientific and non-scientific; finding relevant ways of thinking together". In the research project, explorative pedagogical methods and methods from the geosciences created modes of togetherness between the two disciplines: ECE and the geosciences. These methods were experimented with empirically and included in the work with the preschool children, as shown in the analysis section. Below, I present our experiences from explorative pedagogy from ECE and the geosciences and how they connect to the Swedish preschool curriculum (Swedish National Agency of Education, 2018).

\section{The practice of explorative pedagogy}

As indicated, in this project I situated myself in already existing preschool practices, where exploratory pedagogy was familiar to the children and the teachers. Explorative pedagogy is one of the Swedish preschool's oldest pedagogical methods. Historically it has been called investigative pedagogy, theme- or project-oriented work, and involves different types of observation and documentation practices (Hammarström-Lewenhagen, 2013). This pedagogy draws on a century old preschool tradition, characterised by a holistic view of care and learning, in an international context referred to as the Nordic Edu Care model (Hammarström-Lewenhagen, 2013). In the last 25 years, Swedish ECE practices have also been inspired by the Reggio Emilia philosophy, with dialogue, collaboration, negotiation, and cooperation as key concepts (Gindici, Krechevsky, \& Rinaldi, 2001).

An explorative project takes its starting point in the children's own questions, curiosity, and interests and an understanding of the child as capable of investigating, reflecting on and trying out different solutions to the problems that they and others raise (Vecchi, 2010). This educational approach is in line with the Swedish preschool curriculum, which emphasises and encourages children to test their own and other people's ideas, solve problems and translate ideas into action, both individually and with others (Swedish National Agency for Education, 2018). This resonates with a methodological research approach of starting with children's questions and their matters of concern, which is frequently used within ECE research, as for example Liselotte Mariett Olsson's (2013) investigations on taking children's questions seriously or Iris Duhn's and Sarita Galvez's (2020) methodological approach of being present and entangled with young children's matters of concern. In Sweden, project-oriented explorative pedagogy is considered multidisciplinary and has been further developed in relation to several fields of knowledge, such as science (Åberg \& Lenz Taguchi, 2018), mathematics (Palmer, 2016), gender equality (Lenz Taguchi, Bodén, Ohrlander, 2011) and environmental issues (Elfström, 2013). 
Exploratory working methods are related to documentation and reflection practices, which involve children as participants in investigations, photography, drawing, and structured and informal conversations with others (Lenz Taguchi \& Palmer, 2017). Throughout this project, each child was invited to take part in documentation of the research process through using digital tablets different functions, pens and paper as ways of engaging in their explorations of water purification, their matters of concern, as well as supported in expressing themselves in their preferred manner. The "research" documentation of the research processes and the reflection practices, which closely aligned with the procedures of pedagogical documentation, filled a two-pronged purpose. The documentation produced empirical data as well as being a hands-on procedure supporting the research process. The different types of documentation encouraged the communication of the children's theories, ideas, and deepened knowledge about water purification, which I will show examples of in the analysis section. For me, as researcher, the work with documentation during the research process involved trying to perceive and understand what was going on between the children as well as between the children, water, and the environment. As a means to staying with water, my engagement with the documentation involved offering and presenting possible watery flows to follow by "listening" carefully to the preschool children's questions and ideas without predetermined expectations and norms. Accordingly, listening involved taking into account different children's situated knowledges, embracing that listening involves differences and consensus, as well as paying attention to the children's matters of concern, potentially different than other's and mine (Siry, Brendel and Frisch, 2016).

\section{Inspiration from the geosciences}

The Swedish preschool curriculum has a holistic approach and promotes an education that is based on science and proven experience in terms of the content and working methods used (Swedish National Agency for Education, 2018). This means that facts and notions about environmental issues in the preschool need to be scientifically examined and trustworthy. Including science and scientific facts, for example from the geosciences, in pedagogical work with preschool children is often challenging, in that it requires sensitivity, accuracy, and knowledge about how to verify the information that is found or presented. Other ECE researchers, for example Ingela Elfström, Bodil Nilsson, Lillemor Sterner and Christina Wehner-Godée (2014), show the importance, in a preschool context, of including scientific facts and knowledges as a pedagogical approach to deepen and broaden young children's exploration, theorising and questions regarding the natural sciences. In relation to the research project presented here, it means that I, as the participating researcher, aimed to introduce scientific facts and knowledge in ways that were understandable to the children, when it emerged as vital and addressed the children's interests and concerns. This also involved potential ethical challenges that were not always easy to prepare for, such as when the children were confronted with the fact that many humans and organisms lack access to clean water.

In this study, geoscientific facts about filtration, solar energy, evaporation and droplets are understood as activators (Vecchi, 2010) that trigger the children in their explorations and that link different elements and dimensions together. Furthermore, methods from the geosciences emerged as important and were introduced and incorporated during the children's investigations in various ways during the field period. Some of these methods were simple and involved constructing portable devices, such as mechanical 
filter constructions. In some of the exploration groups, transparent buckets on a rope with a loop for the wrist, specially designed by the children, were used to collect water samples. This resembled the established geoscientific method of collecting water samples for analysing water quality and/or the presence of phytoplankton and zooplankton (Geological Survey of Sweden, 2019). In the same way as geologists and physical geographers engage their bodies as instruments when surveying, the children and I paced the distances between different points in the terrain where they could find water in situ (Crozier, Hardenbicker, \& Gomez, 2010). We also engaged our own bodies, in that touching and smelling emerged as important, while we examined our water samples, for example to estimate the amount of diluted particles, particle sizes and degree of decomposition of organic material in water samples.

\section{The project begins}

In the initial phase of the field period the preschool children and I, in different explorative groups, brought water samples to the preschool, walked around the preschools' surroundings and tasted, smelled, felt, looked at and talked about water in its different physical states (Elkin Postila, 2019). We experimented with icicles, ice cubes and melting and freezing processes outdoors and indoors. During the process we started to pay attention to water as a taken-for-granted commodity in our everyday practices, such as drinking water, flushing toilets, washing hands and brushes after painting, dissolving blocks of colour pigments, constructing with potting clay as well as water play outdoors or indoors in water rooms or on tables set aside for water play (PaciniKetchabaw \& Clark, 2016).

The interest in water purification started with a discussion in one of the exploratory groups, with 14 children aged 5 years, when an urgent and important question was raised at circle time. Alice recounted that the well at her summer house had become dry last summer and William reflected on the stream next to the preschool that was completely dry (Elkin Postila, 2019). These two children's individual local experiences and memories of water, which differed from the children's everyday experiences of water, taps, and tap water at the preschool, evoked the other children's interest and concerns. Astrid and Lucas started to talk animatedly about dirty water, water from wells, the absence of taps and dirty tap water. Matteo moved his hands like water flowing in a river, Elsa jumped up and down to illustrate a waterfall, while Freja nodded in her conversation about deserts with Noah. The children's engagement in the matter of dirty water and absence and presences of water, as I understood it, emerged as common matters of concerns. With the children's permission, the documentation from this, and the meetings that followed, was shared with the other exploratory groups at both preschools, which meant that the preschool children got access to each other's drawings, notes, constructions, picture-presentations, photographs and films, as well as my documentation. The manner of sharing the research project's documentation with each other, created important bridges and connections that facilitated the proliferation, translation, and transformation of constructive ideas and thoughts about water purification amongst the different groups. In the sharing of experiences, other questions arose and other constructions were produced. However, the question of How to clean dirty water? stayed with us throughout the entire research project. 


\section{Stories of solar energy, water filtration machines and water robots}

At circle time the group of 5-year-old children gathered together on a red carpet. I started the meeting by using a pedagogical approach that was familiar to the children: We'll go around the circle so that each one of us, if we want to, can ask a question about water that can be investigated further. The questions differed at times, while at other times they were similar to others (Fig. 1). Then Alma asked: If I got lost in the forest and had no water, how would I survive? Can I drink water from a puddle in the forest, from a stream or from a lake? Can I drink water from the ocean? Alma's questions engaged the children. Liam explained: You need clean water, otherwise you'll be ill. If the water in the stream isn't clean, you can't drink it. Alma added: It is probably not clean if it looks dirty and muddy. At the same time as acknowledging the ethical dimension of the children's queries and thoughts about surviving without water, I followed up the thread of dirty water and told the children about mechanical and technical ways of purifying it. I connected factual knowledge from the natural sciences with Liam's and Alma's s questions and said: You can filter, boil or use solar energy to clean the dirty water. I then encouraged the children in the group to elaborate by drawing on their thoughts and ideas about water purification. Selma, Lucas and Oliver found quiet places to draw in their diaries using colour pencils to illustrate their thinking. While Adam, Alice and Liam looked for information in books, pamphlets and on the internet together with the teachers and me. For Maja, my statement became an activator for her explorations of water purification and solar energy that triggered her. In the following sequence, we follow Maja and her ideas about how to clean water using solar energy.

\section{The story of solar energy}

Maja looked for images of water purifying machines driven by solar cells on the internet and together with a teacher found a reliable website showing the procedure of water being cleaned by solar energy. Together they read that solar powered devices can turn salt water into clean drinking water and produce electricity at the same time. This expertise concerns desalinating or purifying water in places in which fresh water is scarce or contaminated (Leijon, Salar, Engström, Leijon, \& Boström, 2020). This inspired Maja, who drew the dirty water as five waves at the bottom of the rectangular piece of paper (Fig. 2). The two lower waves were not coloured and were followed by a blue, orange and red wave. She drew a framed yellow sun in the upper left-hand corner of the paper. In three blue bubbles Maja drew detailed drawing of a speck of dirt, a germ with two extremities and a cloud. Maja also drew a speck of dirt inside a yellow bubble. At the bottom of the paper, just above the red wave, she drew a red square. Maja also drew six arrows pointing upwards, one under each bubble and under the square. Maja then described the process for the teacher Sam, who wrote the following in Maja's diary: The water is cleaned. The sun heats up the dirty water, which evaporates as steam. The steam turns into droplets that fall into the small container.

On the following explorative meeting Maja showed the drawing with the written text and a developed hypothesis (Figs. 3, 4) to me before we started. I then asked Maja if she could show us and talk about her drawings during the morning meeting. Maja agreed and during the meeting told us: When the sun heated the water, the water vanished, whilst dirt and germs were left. The water turned into drops that got caught on the plastic lid and 
dripped down into the container. The water is cleaned!This relates to what Tsing (2015) writes about storytelling; when sharing, differences are highlighted. In this situation, sharing drew attention to Maja's working process and the different choices she had made to refine her construction.

During and after the session, I studied Maja's drawings from a geoscientific perspective and connected Maja's theorising with a method for solar water disinfection (SoDis) that uses solar energy to clean water contaminated by bacteria, viruses, protozoa, and worms (Climate Technology Centre and Network, 2016). Furthermore, Maja's schematic mode of drawing and use of generalised symbols to signify dirt, sun, clouds, germs, and different levels, and her use of arrows to indicate direction of movement had similarities with the illustrations, or visual descriptions, used in the geosciences to indicate stratifications, angles, directions and inclinations (Crozier et al., 2010) and in mapmaking, where generalised symbols carry thematic information (Hanna, 2010).

When I met the group of 5-year-old children at next explorative meeting, Maja once again wanted to show the other children her drawings and explain them. Maja clarified that the arrow signified direction, force and movement. She turned her body and arms to one side and then the other to illustrate direction, raised her hands to signify an arrowhead and made stiff movements to illustrate the evaporation of water as steam. During Maja's bodily movement, I connected and added geoscientific concepts, such as evaporation, to verbally amplify Maja's explanation. Furthermore, I connected the arrow symbol and use of other symbols with the geoscientific practice of drawing maps in connection with how Selma, Adam and Alice had elaborated their thinking about water purification in their drawings. These practices of bridging and togetherness generated further exploration, for example when I highlighted the concept of solar cells ( $s v$. solceller). In Swedish it is a compound word with subtle shifting sounds, making it difficult to articulate, as Hugo noted while giggling saying: solceller, solceller, solceller over and over again. Furthermore, other children searched for images of solar cells on the internet and found that parking metres and electric bikes could run on energy produced by solar cells. They also found that solar cells had recently been installed on the roof of the royal palace in Stockholm.

\section{The story of water filtration machines and water robots}

Using Maja's own words, written down by the teacher Sam, this is how to build a water filtration machine:

You need two coffee filters, a "self-made" strainer, and a funnel. The dirty water is poured into the machine, it goes into the thin green pipe, then into the thick blue pipe, through filters and pours out as clean water that we can drink.

During the first 3 months of the explorative experimenting, the first hypothesis of how to clean dirty water was elaborated on in numerous drawings and discussions by each child and in the different exploratory groups. In the brief gatherings at the end of each meeting, the children's research documentation, notes, drawings, constructions, photographs, and films were placed side by side with my research documentation. This was done in order to form a broader understanding of what was happening with the various investigations, the possible directions the investigations could take, and which methods were emerging as important during the investigative process (Vecchi, 2010).

In order to stay with the trouble, together with the children, I introduced scientific stories as a method to stay with water in relation to what was going on in the different groups, 
as well as connecting the children's doing, ideas, and explorations with scientific knowledge. This method involved me for example showing photographs and telling stories about water robots cleaning water tanks, streams and oceans from dirt, germs, and plastic. The storytelling transformed the project into to an explorative process in which some children turned their drawings into constructions of water filtration machines or water robots. However, this transformation of the explorations involved challenges for me in that I aimed to let the children's thoughts and ideas steer the investigations, rather than resorting to normative solutions. In other words, situatedness emerged as method in that it made me present in the here-and-now spaces with the children. During this transformation of the explorations, some children's drawings slowly transformed into constructions of recycling materials, tape and steel wire. Other children, like Maja, never translated their drawings into constructions, either because as in Maja's case she preferred to express herself in drawings, or because it was too difficult technically to translate the drawing into a construction. These technical complex drawings were, for example, Alice's flying bat-robot that during night sucked up dirty water with one of its wings, cleaned the water in its interior and emitted clean water through the other wing. Adam's butterfly-robot is another example, which spread droplets of water with its wings during the day, and a third example is Olivia's miniature robots cleaning water inside large water purification robots. This was very frustrating to Alice, Adam, Olivia and me, when we were not able to translate the drawings into constructions. However, in this togetherness of frustration at times other solutions and ideas emerged, such as modifications, changed constructions or simplifications like crumpled pieces of white paper turning into miniature robots.

Elias, on the other hand, turned his hypotheses into constructions without drawing them first. In Elias' case, he made a water filtration machine out of a transparent plastic box, a lid with a hole and a coffee filter inserted into the neck of a bottomless bottle (Fig. 5). Before testing the machine, the teacher Mila summarised in a note what Elias wanted to find out: Will the water percolate from the top of the construction through the filter to the bottom? Will the filter collect the debris from the water? and Will the dirty water become clean by passing through the water filtration machine? Elias tested his construction by pouring water, collected earlier in the forest, from a plastic mug. During the testing, I turned into an attentive observer documenting the event in photographs and verbally connecting the process to geoscientific concepts such as percolation. While the water slowly percolated through the machine, Elias gleefully exclaimed: Yes, it worked! In relation to Elias' enthusiasm I wondered and asked if he had thought of who could use the machine and where one could use it. Elias stated that he had constructed his water filtration machine so it could be used by children in Tanzania, to play with and drink clean water. The teacher Mila, who was standing beside Elias, filled in: Yes, you were there last winter, visiting your grandparents. I then used my own experience from working as a geoscientist in Tanzania and told the children a story about my experiences, starting with: When I was in Tanzania, in a region almost as dry as a desert, the people living there had to walk for many hours to collect clean water... In response to my story Elias told us that his machine could save people from long walks. Through Elias' personal experiences, the rest of us, the other preschool children, myself and Mila, became involved in and engage with an environmental issue far away from Sweden, which connected our local explorations of water at the preschool to a country far away.

At this point I connected Elias' machine with Alma's previous questions about surviving in the forest without water and whether it was possible to drink water from puddles, streams or the sea, in our discussions during the last part of our session. Consequently, by slowing down and staying with, we connected and engaged with the questions posed earlier 
in the project, questions that we had time to think with, feel and reflect upon. This relates to Stengers' (2018) theoretical notion of slowing things down as method, which is also a way of temporarily "freezing" situations in order to understand them in alternative ways. Thus, a slower pace at times allowed us time to think and imagine, as well as creating relations with other things, and producing new things to think about, elaborate on and explore.

In the preschool children's explorations of dirty water and water purification, the 5-yearolds in the group discussed questions which can be understood as ethically difficult. These discussions concerned the access of water at different preschools in Sweden and Tanzania and preschool children's possibilities to bring water on walks in forests and bushlands in these countries. The discussions also involved the potential dangers for humans and other organisms of drinking stagnant water, as Oliva, Selma and Lucas addressed. All these questions touched upon feelings and inequalities among children in different parts of the world, which I found quite difficult and ethically complicated. However, the children approached these questions by acting and immediately started to make constructions to solve the problems they identified. The conversations activated building and constructing sessions where the children created portable, personalised water-cleaning machines fitted as backpacks. To get the right personal dimensions, the children used tape measures, which were then noted on the drawings and later used to find recycling material with the proper dimensions for constructing the machines. Without hesitation, the children approached these entangled ethical questions that had been produced in and through their hands-on-work and they found creative ways to think about how to clean water. Through this specific explorative group's previous engagement and experiences of and with water in different forms, water emerged as a perishable commodity that could be polluted and contaminated by organic debris and waste and/or be stagnant.

\section{The story of testing}

After two weeks of constructing and modifying their water filtration machines, Wilma, Elsa and Signe moved their constructions outdoors to the preschool porch for testing. They also used water collected outdoors for testing the machines. Wilma's machine was a construction consisting of a coffee filter inserted into the neck of a bottle in order to clean the water by vertical drop. Before starting to pour the water into the filter, Wilma gave me instructions about how to film the testing sequence. She then poured the water into the machine using a watering can, while I adopted the role of an observer and documenter, filming the event and talking with the children during the testing. Elsa also poured water from a watering can into her machine, which was constructed like Wilma's but with a difference, the coffee filter was placed on the outside of a bottomless bottle (Fig. 6). Elsa instructed me to take photographs during her testing. Signe also tested her machine, made according to a similar concept, but this time with the filter inside a funnel made out of a plastic bottle. All three constructions fulfilled the requirements of transporting water from top to bottom, although how efficient they were in cleaning the water was difficult to evaluate. Together, Wilma, Elsa, Signe and I noted that Signe's water looked cleaner after the mechanical filtration than the other water samples. I then drew attention to the differences between the constructions with regard to the position of the filter, and ambitiously connected the position with the amount of debris in the filtered water and how this procedure was similar to the cleansing of water in the municipality's huge water treatment plant. However, rather than connecting or engaging in these questions, Wilma, Elsa and Signe were more interested in pouring the water into the machines and the movement of water 
from one place to another; an activity that Wilma, Elsa and Signe continued to engage with after the testing rounds.

After this first testing group, it was time for Alma, Theo and Liam to test their water purification constructions. These machines differed slightly from the first group's constructions and consisted of two containers separated by different filters (Fig. 7). They tested their machines and saw that the water passed through the different filters. The three constructions fulfilled the requirements of transporting water from top to bottom. Furthermore, the water came out cleaner than before the filtration, because the filters collected the debris from the sample. Alma, Theo and Liam documented their testing procedures by filming with a digital tablet, together with detailed verbal explanations, while I only participated when the children asked me to hold the devices. During the testing Alma, Theo and Liam reflected on their constructions and whether or not they fulfilled the requirements of cleaning the dirty water. They noted how they could modify the constructions to better serve the purpose of cleaning. The modification of their constructions continued throughout the field period and extended to other occasions than the specific explorative meetings involving me and my research concerns.

\section{Staying with the trouble-concluding discussion}

In my rethinking of environmental education in preschool, I have engaged in and connected with three watery stories from an explorative and multidisciplinary intervention project with preschool children. In doing so I have engaged with and in the children's situated knowledge, their matters of concern regarding water purification and the documentation produced during the research process. In my construction of this article's stories, I have tried to stay truly present with data and the children's detailed stories about water. As Haraway (2016) writes, stories help us remember what we thought we knew, or introduce us to new knowledge, as a way of knowing and learning with others. In this case, I have learned with the preschool children, but also with water, facts and documentation such as films, photographs, notes, and drawings. Together with theory, I situated myself in the stories presented above and explored what we, me, and the children, could learn from and with them. By that I practised what staying with the trouble might involve and mean, while striving to think with children, water, stories, facts, and fiction. This endeavour and the results from the study are summarised below.

In the story of solar energy, when I engaged and connected with Maja's stories and her idea that water could be cleaned using solar energy, I connected with her search for information on the subject on the internet, her questions and elaborations on how to clean water. In her explorations of how to clean it, Maja expressed her ideas through drawings in which she made use of symbols, for example arrows to indicate direction. During her explorations Maja modified her ideas in detailed drawings. By connecting and engaging in Maja's explorative process, I learned about her understanding of dirty water and how to clean it. I understand this type of exchange of knowledge as being important for continued collaboration and the explorative process.

Furthermore, in the story of water filtration machines and water robots, Elias' stories and engagement with water and the construction of water filtration machines highlight the importance of letting children's situated knowledge be part of their investigations and explorations of cleaning water. In Elias' story, he makes use of his experiences in Tanzania and his relations to a place in which access to water is different to than in Sweden. 
Elias' experience and knowledge not only made him engaged in his explorations of water filtration machines and how to clean dirty water, but also his experiences and engagement involved the other children in ethical and existential questions. If the children had not found these ethical and existential questions important, I would have found these particular questions difficult to introduce to a group of preschool children. However, in today's climate change I realise these ethical issues are important to address in all forms of education, as well as the need to explore ways to be with these complexed issues together with children. In their complexity these questions and explorations of dirty water and water purification, relates for instance to children's right to clean water (UN, 2010) and children's right to education (UN, 1989). Questions, which draw attention to inequalities in relation to access to clean water and sanitation and the consequences for children's possibilities to attend education (UN-Water, 2015). Thus, existential and ethical topics relevant and important to stay with and draw attention to in environmental education in present time of climate change, despite the children's age. In this case, the question came from one of the children which made it easier to discuss it in an undramatic manner.

In the story of testing Alma's, Liam's and Theo's explorations and investigations of dirty water and how to clean it, closely aligned with deductive methodological procedures common in the natural sciences (Elfström et al., 2014). Alma, Liam and Theo described their hypotheses in drawings, the drawings then transformed into constructions, which were evaluated by testing and adjusted to achieve their goal of clean water (Rhoads \& Wilson, 2010). This "scientific model" was maintained during Alma's, Liam's and Theo's further explorations and investigations of developing water-cleaning machines by using different techniques, materials and tools. In this process, geoscientific facts and methods supported their explorations and constructions as activators, or "important stuff to think with", following Stengers (2018, p. 16). The documentation was also an important activator to connect and engage with, in terms of staying with and slowing down the explorative process as well as being reminders enabling the children to learn with others and plan for the next step in their explorations.

In relation to Wilma's, Elsa's and Signe's stories, Elias' engagement and devotion to his matter of concern may perceived as specific and correct. However, I argue that Wilma's, Elsa's and Signe's engagement in their friends' ideas, solutions and the movement of water, their matter of concern and their engagement also is important and valuable. Thus, the children explored questions of how to clean water from many different disciplines and angles in a multidisciplinary way. This relates to Stengers (2018) suggestion to start in the problem and then decide which disciplines to engage with to solve the problem.

This article highlights that the children's matter of concern, the problems to stay with, varied. While Wilma's, Elsa's and Signe's concern involved exploring the movement and pouring of water as phenomena, Alma, Theo and Liam explored water purification by constructing a machine to clean it and continued their modifications throughout the field period. I connect this extended devotion and engagement with how to construct water filtration machines with Alma's questions about how to survive in the forest without water, and Alma's and Liam's discussions about dirty water that followed. Thus, some of the children in the project engaged in and devoted themselves in their matter of concern, which contributed to the children staying with the trouble throughout the project. When discussing their thoughts and findings with me, these became part of the research project, thus shaping and transforming the project. Furthermore, the questions and findings joined in the creation of a "we" and a togetherness with other children, water, me, the surrounding materials and facts in order to exchange ideas and discoveries (Stengers, 2018). A framework was set up in which curiosity led the work. 
This project also shows that even though my expertise in both early childhood education and the geosciences was important, it was challenging to stay present with the children and my aim of the project. This involved challenges such as letting the child(en)'s concerns matter, rather than starting in a predetermined matter of facts. Furthermore, in relation to the child(en)'s matter of concern introducing scientific facts and knowledge in ways understandable to the child(ren). The methods from the geosciences emerged as activators and bridge-builders by connecting different disciplines and knowledges, thus deepening and widening the children's explorations with water purification. In addition, geoscientific information, facts and tools became important things to think with, which navigated the children and their explorations in sometimes new directions.

\section{At last...consequences for environmental education}

In this article I have taken on Haraway's (2016) call of staying with the trouble, together with preschool children in investigations of dirty water and water purification, to rethink and explore what it might become in preschool environmental education. In doing this I have addressed the two-pronged mission proposed in the Swedish preschool curriculum to invite children to explore and investigate their surrounding environment here-and-now, through the hands-on explorations we carried out. These explorations created relations between the children, between children and water as well as relations between the local and the global. The children's situated questions connected to global discussions about climate change and environmental issues, such as water shortages and polluted seas and streams in the neighbourhood and countries far away such as Tanzania. To make these relations visible, to stay with the children and their questions as well as daring to take their questions seriously, was not an easy task and many of the children's questions remained unanswered. Furthermore, each of the three stories of water constructed from our joint pile of data involves multiple further stories of water, none of which were just particular nor just global, but rather always stories of simultaneity.

My methodological approach of intervening by situating myself in ongoing practices as well as the practice of telling and listening to stories (Tsing, 2015), involved slowing down the pace, repeating different phases, and sometimes delaying the creative and collaborative process to provide time to reflect on and scrutinise the investigations of water purification from different perspectives. This connects to Stengers (2018) description of a practice of togetherness where different scientific and non-scientific practices emerge and work together, where it is possible to find relevant ways of thinking together. This involved (re) connection with the particular, local and global stories of water, children's intricate relations as well as connecting with young children's matters of concern, situated knowledges, practices and methods of investigating and exploring.

I would like to stress the importance of the children in this research project. The children indeed are the experts of their practices, involved in locally situated time-place research, in investigating and rethinking environmental education through their concerns regarding cleaning dirty water. This resonates with Stengers (2018) reasoning about connoisseurs and how connoisseurs, the producers of local knowledge, are the experts of their local practices. The children are the connoisseurs, the producers of local knowledge in their expertise of their preschools and their surroundings. Furthermore, I acknowledge the importance of the preschool teachers' as connoisseurs throughout the research project, making it possible through their expertise of the preschool practices and activities and their knowledge about the individual preschool children and the dynamics within the preschool groups. 
At last, an overall theme in this article is bridge-building practices, where different practices are curiously engaged with and presented to each other (Stengers, 2010). These meetings between practices, have created "intelligent relationships" (Stengers, 2018, p. 4) between the preschool children, me and the preschool teachers, our different disciplines, and practices, with the potential to rethink environmental education by taking preschool children's investigations of dirty water and water purification seriously. The study can be seen as an invitation to preschools to engage in the debate on climate change, and to create a togetherness around environmental concerns, not only in the future, but also here-andnow in the preschool.

Acknowledgements I would like to thank all the children who took part in this project for sharing their documentation of water and water purification. Warm thanks also go to the teachers for their engagement in the project. I also would like to take the opportunity to thank the lead editor Maria Andree and the reviewers of this article: Steve Alsop and Cecilia Caiman. I greatly appreciate their valuable comments and suggestions that helped me improve the quality of the article.

Funding Open access funding provided by Stockholm University.

Open Access This article is licensed under a Creative Commons Attribution 4.0 International License, which permits use, sharing, adaptation, distribution and reproduction in any medium or format, as long as you give appropriate credit to the original author(s) and the source, provide a link to the Creative Commons licence, and indicate if changes were made. The images or other third party material in this article are included in the article's Creative Commons licence, unless indicated otherwise in a credit line to the material. If material is not included in the article's Creative Commons licence and your intended use is not permitted by statutory regulation or exceeds the permitted use, you will need to obtain permission directly from the copyright holder. To view a copy of this licence, visit http://creativecommons.org/licenses/by/4.0/.

\section{References}

Åberg, A., \& Lenz Taguchi, H. (2018). Lyssnandets pedagogik: Etik och demokrati i pedagogiskt arbete. [The pedagogy of listening: Ethics and democracy in pedagogical work] (2nd ed.). Liber.

Aronsson, L. (2019). När förskolan möter neurovetenskap: Kunskapsteoretiska möten i teori och i praktik [When preschool meets neuroscience: Epistemological encounters in theory and in practice]. Diss. Stockholm University.

Bates, B. C., Kundzewicz, Z. W., Wu, S., \& Palutikof, J. P. (Eds.). (2008). Climate change and water: Technical paper of the intergovernmental panel on climate change. IPCC Secretariat.

Climate Technology Centre and Network. (2016). Solar water purification. Retrieved from Solar water disinfection I Climate Technology Centre \& Network I Tue, 11/08/2016 (ctc-n.org).

Crinall, S., \& Somerville, M. (2020). Informal environmental learning: The sustaining nature of daily child/ water/dirt relations. Environmental Education Research, 26(9-10), 1313-1324. https://doi.org/10. 1080/13504622.2019.1577953

Crozier, M. J., Hardenbricker, U., \& Gomez, B. (2010). Physical landscape. In B. Gomez \& J. P. Jones III. (Eds.), Research methods in geography: A critical introduction (pp. 93-115). Wiley-Blackwell.

Duhn, I., \& Galvez, S. (2020). Becoming curious research to cultivate tentacular becomings. Environmental Education Research, 26(5), 731-741. https://doi.org/10.1080/13504622.2020.1748176

Elfström, I. (2013). Uppföljning och utvärdering för förändring: Pedagogisk dokumentation som grund för kontinuerlig verksamhetsutveckling och systematiskt kvalitetsarbete i förskolan. [Assessment and evaluation for change: Pedagogical documentation as foundation for continuous development of practice and systematic quality work in early childhood education]. Diss. Stockholm University.

Elfström, I., Nilsson, B., Sterner, L., \& Wehner-Godée, C. (2014). Barn och naturvetenskap: Upptäcka, utforska, lära i förskola och skola [Children and science: Discover, explore, learn in preschool and school]. Liber AB.

Elkin Postila, T. (2019). Water as method: Explorations of locally situated environmental issues together with preschool children. Australian Journal of Environmental Education, 35(3), 222-229. https://doi. org/10.1017/aee.2019.27 
Eriksson, C. (2020). A preschool that brings children into public space: Onto-epistemological research methods of vocal strolls, metaphors, mappings and preschool displacements. Diss. Stockholm University.

European Parliament and Council. (2016). Regulation (EU) 2016/676. Retrieved from http://data.europa.eu/ eli/reg/2016/679/oj. Accessed 6 April 2021.

Geological Survey of Sweden. (2019). Metod för kartläggning och påverkan av grundvatten. [Method for mapping and impact of groundwater]. Retrieved from Metod för kartläggning och påverkansbedömning av grundvatten (sgu.se).

Gindici, C., Krechevsky, M., \& Rinaldi, C. (Eds.) (2001). Making learning visible: Children as individual and group learners. (translated by J. Costa, G. Grasselli, \& L. Morrow). Reggio Emilia: Reggio Children Publishing.

Hammarström-Lewenhagen, B. (2013). Den unika möjligheten: En studie av den svenska förskolemodellen 1968-1998. [The unique possibility: A study of the Swedish preschool-model 1968-1998]. Diss. Stockholm University.

Hanna, S. P. (2010). Maps and diagrams. In B. Gomez \& J. P. Jones III. (Eds.), Research methods in geography: A critical introduction (pp. 260-278). Wiley-Blackwell.

Haraway, D. (1988). Situated knowledges: The science question in feminism and the privilege of partial perspective. Feminist Studies, 14(3), 575-599. https://doi.org/10.2307/3178066

Haraway, D. (2016). Staying with the trouble: Making kin in the Chtulucene. Duke University Press.

Leijon, J., Salar, D., Engström, J., Leijon, M., \& Boström, C. (2020). Variable renewable energy sources for powering reverse osmosis desalination, with a case study of wave powered desalination for Kilifi, Kenya. Desalination, 494, 1-9.

Lenz Taguchi, H., Bodén, L., \& Ohrlander, K. (Eds.) (2011). En rosa pedagogik: Jämställdhetspedagogiska utmaningar. [A pink pedagogy: Gender equality pedagogical challenges]. Liber AB.

Lenz Taguchi, H., \& Palmer, A. (2017). Dokumentation för lärande. SEMLA: Socioemotionellt och materiellt lärande i förskolan. [Documentation for learning. SEMLA: Socio-emotional and material learning in preschool]. In A-L. Lindgren, N. Pramling, \& R. Säljö (Eds.), Förskolan och barns utveckling: grundbok för förskollärare. [Preschool and children's development: Basic book for preschool teachers] (pp. 245-261). Gleerups.

Nxumalo, F., \& Pacini-Ketchebaw, V. (2017). 'Staying with the trouble' in child-insect-educator common worlds. Environmental Education Research, 23(10), 1414-1426. https://doi.org/10.1080/ 13504622.2017.1325447

Nxumalo, F., \& Villanueva, M. (2019). Decolonial water stories: Affective pedagogies with young children. The International Journal of Early Childhood Environmental Education, 7(1), 40-56.

Olsson, L. M. (2013). Taking children's questions seriously: The need for creative thought. Global Studies of Childhood, 3(3), 230-253.

Pacini-Ketchabaw, V., \& Clark, V. (2016). Following watery relations in early childhood pedagogies. Journal of Early Childhood Research, 14(1), 98-111. https://doi.org/10.1177/1476718X14529281

Palmer, A. (2016). 'Is this the tallest building in the world?' A posthuman approach to ethical dilemmas in young children's learning projects. Global Studies of Childhood, 6(3), 283-298. https://doi.org/ $10.1177 / 2043610616665035$

Rhoads, B. L., \& Wilson, B. (2010). Observing our world. In B. Gomez \& J. P. Jones III. (Eds.), Research methods in geography: A critical introduction (pp. 26-40). Wiley-Blackwell.

SFS. (2003:460). Act concerning the ethical review of research involving humans. Ministry of education.

Siry, C., Brendel, M., \& Frisch, R. (2016). Radical listening and dialogue in education research. International Journal of Critical Pedagogy, 7(3), 119-135.

Statistics Sweden. (2020a). Names: newborn boys 2019, top 100. Retrieved from Names-newborn boys 2020, top 100 (scb.se).

Statistics Sweden. (2020b). Names: newborn girls 2019, top 100. Retrieved from Names-newborn girls 2020, top 100 (scb.se).

Stengers, I. (2010). Cosmopolitics I. (translated by R. Bononno). University of Minnesota Press.

Stengers, I. (2018). Another science is possible: A manifesto for slow science. (translated by S. Muecke). Polity.

Swedish Civil Contingencies Agency. (2020). Barn vid vatten. [Children by the water]. Retrieved from https://www.dinsakerhet.se/sakrare-fritid/hav-och-sjo/barn-vid-vatten/. Accessed 6 April 2021.

Swedish National Agency for Education. (2018). Curriculum for the preschool: Lpfö 18. Swedish National Agency for Education.

Swedish Research Council. (2017). Good research practices. Stockholm: Swedish research council. Retrieved from https://www.vr.se/english/analysis/reports/our-reports/2017-08-31-good-researchpractice.html. Accessed 6 April 2021. 
Taylor, A. (2020). Countering the conceits of the anthropos: scaling down and researching with minor players. Discourse: Studies in the Cultural Politics of Education, 41(3), 340-358. https://doi.org/ 10.1080/01596306.2019.1583822

Taylor, A., \& Pacini-Ketchabaw, V. (2015). Learning with children, ants, and worms in the Anthropocene: Towards a common world pedagogy of multispecies vulnerability. Pedagogy, Culture \& Society, 23(4), 507-529. https://doi.org/10.1080/14681366.2015.1039050

Tsing, A. L. (2015). The mushroom at the end of the world: on the possibility of life in capitalist ruins. Princeton University Press.

UN. (1948). The Declaration of Human Rights. Retrieved from Universal Declaration of Human Rights I United Nations.

UN. (1989). The United Nations Convention of Rights of the Child. Retrieved from OHCHR I Convention on the Rights of the Child.

UN. (2010). The human right to water and sanitation: resolution. Retrieved from https://www.un.org/en/ga/ search/view_doc.asp?symbol=A/RES/64/292. Accessed 6 April 2021.

UN-Water. (2015). Eliminating Discrimination and Inequalities in Access to Water and Sanitation. Retrieved from https://www.unwater.org/publications/eliminating-discrimination-inequalities-accesswater-sanitation/. Accessed 6 April 2021.

Vecchi, V. (2010). Art and Creativity in Reggio Emilia: Exploring the role and potential of ateliers in early childhood education. Routledge.

World Medical Association. ([1964]2008). WMA declaration of Helsinki: ethical principles for medical research involving human subjects. Retrieved from https://www.wma.net/policies-post/wma-decla ration-of-helsinki-ethical-principles-for-medical-research-involving-human-subjects/. Accessed 6 April 2021.

Publisher's Note Springer Nature remains neutral with regard to jurisdictional claims in published maps and institutional affiliations.

Teresa Elkin Postila, MSc GeoSc., MSc Edu. is a doctoral student in early childhood education at the Department of child and youth studies, Stockholm university. In her thesis project, she combines her academic backgrounds from the geosciences and early childhood education in her and preschool children's explorations of environmental issues concerning water. 